\title{
Mediated Effect of Employee Job Satisfaction on Employees' Happiness at Work and Analysis of Motivational Factors: Evidence from Telecommunication Sector
}

\section{Rehan Sohail Butt ${ }^{\circledR}$ Xuezhou Wen ${ }^{2}$ Rana Yassir Hussain ${ }^{3}$}

${ }^{1, s}$ School of Management, Jiangsu University, China. Email:5103170238@stmail.ujs.edu.cn Tel: +8618651925560 Email.hussainooo4@vahoo.com Tel.+86186508s1975

'School of Management, Jiangsu University, China/School of Business, Jiangnan University, China. 'Email:1002283834@qq.com Tel: +861386139914

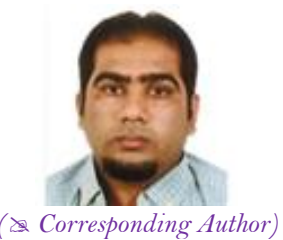

D) Check for updates

\begin{abstract}
Happiness at the workplace is an important ingredient in improving productivity at any organization. This study, therefore, sought to examine the effect of employee job satisfaction on employee's happiness at work among telecommunication workers in Pakistan. The study was anchored on the motivation theory and includes some factors that influence motivation at the work place. The motivational factors include job inspiration, job security, benefits/salary, work environment and leadership. These motivational factors are expected to influence the dependent variable (happiness at work) through a mediating variable (employee job satisfaction). Employee job satisfaction functioning as an independent variable is also expected to influence the exogenous variable (happiness at work). Data for the study was obtained from a sample of 515 telecoms workers from Pakistan using a structured questionnaire. The data was analyzed through Structural Equation Modeling via SPSS 22 and SmartPLS 3.0. Findings from this study indicate factors that determine or influence employees' job satisfaction are job inspiration, benefits, job security, and leadership in that order. The study further found a positive and significant relationship between the independent variables (job inspiration and benefits) and employee job satisfaction. Also, the study found that employee job satisfaction has a positive and significant influence on happiness at work. The study builds on the empirical findings on factors influencing employee job satisfaction by linking it with happiness at work in the telecoms sector This study contributes to the extant literature on happiness at work and makes valuable contribution to future research in this area.
\end{abstract}

Keywords: Employee job satisfaction, Job inspiration, Job security, Leadership, Happiness at work, Work environment JEL Classification: L29.

\section{Introduction}

Satisfied employees would work hard and put much effort their work in order to be more productive and efficient. When employees are satisfied with the work they do, they become happy and produce better results than when they are unhappy. Employee job satisfaction according to Gu, Zhen, Song, and Xu (2019) is "a measure of people's contentedness with their job and an assessment of their work experience". One of the earliest definitions of job satisfaction as "a pleasurable or positive emotional state resulting from one's work or work experiences" (Gu et al., 2019).

Job satisfaction would thus influence how employees work and the level of involvement and commitment they put in their work. mentioned four dimensions that have a great impact on employee job satisfaction as salary, efficiency in work, fringe supervision (Khuong \& Tien, 2013).

Satisfaction is a term that has been frequently used interchangeably with happiness. According to the Oxford English Dictionary, happiness is "a state of mind or feeling comprising contentment, satisfaction, pleasure or joy". Happiness has been used in the literature frequently and interchangeably with other terms such as "subjective wellbeing" "psychological wellbeing", and "satisfaction" (Ryff \& Singer, 2008; Wright \& Cropanzano, 2007). Achor (2010)opine that happy people create successful careers for themselves due to the fact that they find happiness in the workplace.

Wesarat, Sharif, and Abdul Majid (2015) are also of the opinion that happiness at the workplace means the satisfaction employees obtain with the nature of work and their personal lives. This idea is related to individual's subjective well-being; i.e. how satisfied people are with their work environment. Being happy at the workplace is an important factor for improving an organization's performance (Wesarat et al., 2015). Happy people would thus be more productive and efficient at the work they do compare with unhappy employees.

Asiyabi and Mirabi (2012) suggest that being happy for employees could mean that employees would transfer their happiness from office to home and vice versa. A happy employee would thus make a productive and efficient 
workforce for the firm. Despite the importance of happiness to individuals and organizations, the concept is however still vague. Researchers are yet to come to an agreement with regards to what constitutes happiness in the workplace. The concept has been a subject of debate from earliest times within philosophy (Cahn \& Vitrano, 2008).

Additionally, although there is a considerable amount of literature on the subject, it appears however that only a handful of scientific theory research has been undertaken thus far from organisational perspective (McGonagle, 2015). Also, "a robust framework for application in the work setting is still missing"(Tasnim, 2016) and this calls for extensive research in that regard to fill the gap in theory. This study, therefore, aims at bridging the gap in theory and literature. Thus, this study focuses on finding out factors influencing employees' job satisfaction and how does job satisfaction influence happiness in the workplace. The main objective of this study, therefore, is to explore factors influencing employee job satisfaction among telecommunication workers in Pakistan. This study thus seeks to achieve the following objectives;

1. Identify factors that influence employee job satisfaction among telecommunication workers in Pakistan.

2. Assess the effect of employee job satisfaction on employees' happiness at work.

\section{Theoretical Underpinnings}

\subsection{Employee Job Satisfaction}

Brief (1998) defined job satisfaction as "an internal state that was expressed by effectively or cognitively evaluating an experienced job with some degree of favour or disfavor". Spector (1997) on the other hand defined employee job satisfaction to mean an individual's satisfaction with his/her job, indicating whether or not he or she likes the job. Motivating and retaining qualified employees thus is very important in ensuring the success of organizations (Sohail \& Jang, 2017). The Oxford dictionary also defines satisfaction as "the feeling of pleasure that arises when you have the things you want or need or when the things you want to happen".

Rice, McFarlin, and Bennett (1989) opined that satisfaction is determined by comparing current job experiences against some personal set standards and then evaluating whether one is satisfied with the current job or not (Khuong \& Tien, 2013). Herzberg (1968) provided the earliest known investigation into the factors that lead to job satisfaction. In his study, Herzberg interviewed a group of employees to determine what made them satisfied or dissatisfied with their job. He classified these factors as motivators and hygiene factors (Herzberg, 1968). Motivators-hygiene factors theory revealed that factors determining job satisfaction were distinct from factors influencing job dissatisfaction (Khuong \& Tien, 2013). Hygiene factors also known as job 'dissatisfies' include company policy, administration, supervision, salary, interpersonal relations, and working conditions. Motivators, on the other hand, known as job 'satisfiers' included achievement, recognition, work itself, and responsibility (Sowmya \& Panchanatham, 2011).

With the turn of the 21 st century, various scholars have provided new definitions and constituents of employee job satisfaction. Pearson (1991) for instance mentioned the factors that influence employee job satisfaction as payment, promotion, and autonomy. Arsic, Nikolic, Zivkovic, Urosevic, and Mihajlovic (2012) on their part using the elements of TQM practice mentioned that factors that influenced employee job satisfaction are top management commitment, employee empowerment, teamwork, job evaluation, employee compensation (Khuong \& Tien, 2013). Jun, Cai, and Shin (2006) also using the TQM added that factors influencing employee job satisfaction included employee empowerment, teamwork, and employee compensation.

\subsection{Materials and Hypotheses}

\subsubsection{Benefits/Salaries}

Compensation or benefits has been identified as one of the key influencing factors of employee job satisfaction. Compensation management is a fundamental content of human resources management in organizations (Hee, Yi, Ping, Kowang, \& Fei, 2019). Strategy development and human resource development of organizations have been closely related to compensation management. According to Hee et al. (2019) six different employee compensation systems paid by companies are job-based pay, skill or experience-based pay, broad banding with salary arrays, team-based pay, variable compensation, and executive compensation. Empirical findings have linked employee job satisfaction with benefits or salaries. Nguyen, Taylor, and Bradley (2003) concluded that job satisfaction is the result of promotion opportunities in the organization. Tessema and Soeters (2006) also reported positive relationship between promotion practices and employee performance. Khan., Nawaz, Aleem, and Hamed (2012) also found that factors such as pay and promotion influence employee job satisfaction and performance. Based on the above, we formulate the hypothesis:

H1:Benefits/Salaries have a positive influence on employee job satisfaction.

\subsubsection{Job Inspiration}

Job inspiration implies that employees are satisfied with their assigned jobs, and are able to achieve goals. Meaningful activity, including work (Warr, 2007) and philanthropic activity, including volunteering jobs, has been shown to impact happiness positively (Meier \& Stutzer, 2008). Much of the studies on employee happiness at work reveal that factors such as stable job, challenging, and interesting work enhance work attitudes and improves employee happiness (Fisher, 2010). Available evidence shows that the above-mentioned factors are positively related to employee happiness, and jointly explain job satisfaction in organizations (Fisher, 2010).

Wesarat et al. (2015) mentioned that work activities are job undertakings engaged in by employees. Whiles some employees are excited about their job or task others are not which leads to negative experiences at work (Siegall \& McDonald, 2004). Employees thus could have different satisfaction levels at work doing various work activities which would result in happiness at work (Tadić, Bakker, \& Oerlemans, 2013). Employees engage in meaningful work activities when they feel excited or happy in their job. Managers must, therefore, identify source of meaningful work and ensure that employees get satisfaction in their work (Cleavenger \& Munyon, 2013; Vasconcelos, 2008). If employees recognize reasons or inspirations in carrying out meaningful work, they may be happy to do their work (Dimitrov, 2012; MacMillan, 2009). We hypothesis that:

H2: Job inspiration has a positive and significant effect on employee's job satisfaction. 


\subsubsection{Job Security}

Job security refers to employees' assurance or belief that they will keep their current job. Employees with "a high level of job security have a low probability of losing their job in the near future" (Sageer, Rafat, \& Agarwal, 2012). Employees are always on the edge fearing the possibility of their employment being terminated. This fear puts them in a rather defensive position and are not happy at work due to the uncertainty about their future. As a result, employees might display a certain level of unhappiness with their work. Past studies have been conducted to find out whether or not job security has a negative influence on employees 'happiness. Khan, Nawaz, Aleem, and Hamed (2015) found a positive relationship between job security and employee satisfaction among medical staff in Pakistan. We propose the hypothesis that:

H3: Job security would have a significant and positive influence on employee job satisfaction at the workplace.

\subsubsection{Leadership}

Organizations promote and create happiness for employees through motivation, awareness, and being dedicated to employees' welfare. Good leaders engage in 2-way, transparent communication with their staff as well as ensuring conducive work atmosphere for their staff. Employee happiness at work therefore is dependent on the leader's behavior. As Warr (2007) noted, "a positive leader's behavior is one that includes willingness to listen to employees, showing support, respect and concern for employees' welfare, and a tendency to show appreciation for employees and their work well done" (Stoi, 2016). Thus, a good leader must consider employees feelings and provide inspiration, that would encourage and give meaning to employees' work (Cleavenger \& Munyon, 2013; Vasconcelos, 2008). Stoi (2016) argues that employees achieve some level of satisfaction when the organisation places some importance to the work they do (Dimitrov, 2012; MacMillan, 2009). Thus employees who are satisfied with their leadership would be satisfied with their work and eventually find happiness.

Orthodoxia, Kourtesopoulou, and Kriemadis (2019) examined the relationship between leadership behaviors and job satisfaction and found a significant positive relationship between transformational and transactional leadership behaviors and employee job satisfaction. Also, investigating leadership style in Dutch firms, Vermeeren, Kuipers, and Steijn (2014) found a positive relationship between leadership style and employees' satisfaction. We hypothesis thus:

H4: Leadership would have a positive influence on employee's job satisfaction.

\subsubsection{Work Environment}

Working environment according to Raziq and Maulabakhsh (2015) involves two broader dimensions, work and context. Work accordingly to them includes different characteristics and tasks such as "training, control one's own job-related activities, a sense of achievement from work, variety in tasks and the intrinsic value for a task" (Raziq \& Maulabakhsh, 2015). Context on the other hand comprises the physical working conditions and the social working conditions (Gazioglu \& Tansel, 2006; Skalli, Theodossiou, \& Vasileiou, 2008). Spector (1997) also explained the working environment as consisting of "safety to employees, job security, good relations with co-workers, recognition for good performance, motivation for performing well and participation in the decision-making process of the firm". He further explained that when employees realize how high in esteem the firm holds them, they will have a high level of commitment and a sense of ownership for their organization (Raziq \& Maulabakhsh, 2015). Available literature has suggested a positive and direct link between work environment and job satisfaction. Buhai, Cottini, and Nielseny (2008) found that firms' productivity can be increased by improving the physical dimensions of the work environment (Raziq \& Maulabakhsh, 2015). Bakotic and Babic (2013) also found a positive relationship between working conditions and employee job satisfaction. They mentioned the working condition as an important factor for job satisfaction, and which might also lead to employees 'dissatisfaction. A study by Tariq, Ramzan, and Riaz (2013) in telecom sector revealed that factors such as workload, salary, stress, and conflicts with family due to job would lead to employee dissatisfaction. We hypothesize thus;

H5: Working environment would have a positive or negative influence on employee job satisfaction at the workplace.

\subsubsection{Relationship between Employee Job Satisfaction and Happiness at Work}

Satisfaction is a term that has been frequently used interchangeably with happiness. There is an "affective component" to satisfaction as well as "a cognitive evaluative component" which involves making a judgment with regards to individual needs wants and if these have been achieved (McGonagle, 2015). De Witte et al. (2010) investigated the relationship between job insecurity and happiness and found that there is a significant negative impact of job insecurity on happiness. Wegge, Van Dick, Fisher, Wecking, and Moltzen (2006) also investigated the relationship between organizational identity, job satisfaction, and employee's well-being and found that organizational identity predicted job satisfaction and employee's well-being (Wegge et al., 2006).

H6: Employee job satisfaction has a positive and significant effect on happiness at work.

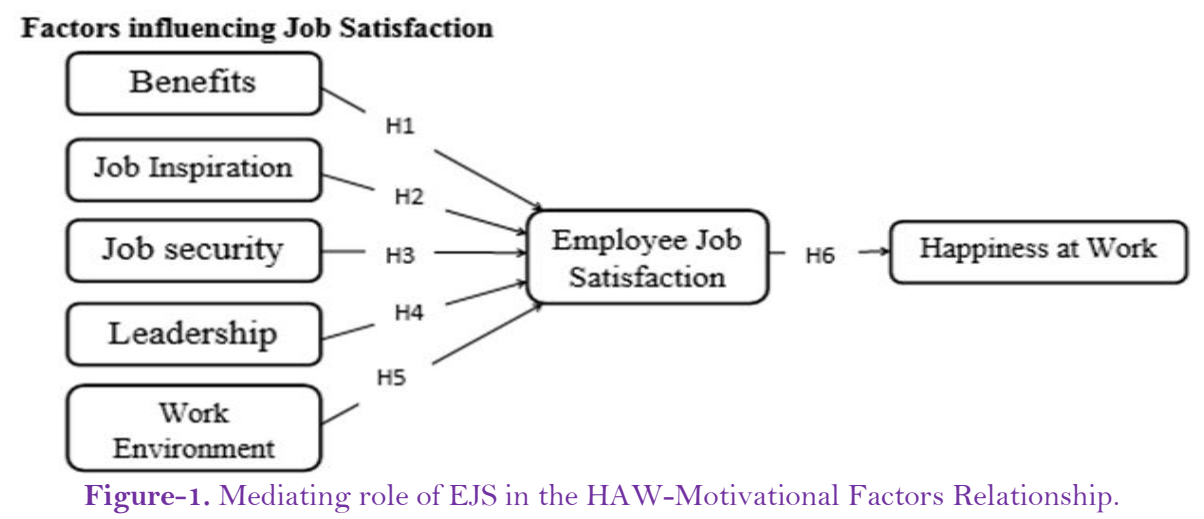




\section{Methodology}

The survey method was utilized in this study to assess factors that influence employees' job satisfaction as well as the effect of job satisfaction on employees' happiness at work. The survey method was chosen because it suited the purpose and nature of this research. A convenient sampling technique was used to sample 515 telecommunication workers in Pakistan see Table 2. Data for the study was obtained through a structured questionnaire developed using previous scale. The questionnaire was pre-tested and self-administered to the respondents by the researcher and trained field researchers. The respondents were all well informed about the study and their approval was sought before distributing the questionnaire to them. Also, the researchers assured the respondents of anonymity and confidentiality of their responses. A five-point Likert scale which option ranging from strongly disagree (1) to strongly agree (5) was used to measure variables for the research constructs as recommended in previous studies. The questionnaire consisted of 54 multi measurement items and six demographic questions see Table 2.

The collected data was cleaned, sorted and coded using the Statistical Package for Social Sciences (SPSS V.22). An exploratory factor analysis (EFA) was then performed via SPSS to assess the factor loadings of the individual constructs in the conceptual model. The EFA was thus carried out for these three reasons: "(1) Assess the suitability of the data for factor analysis, (2) Factor extraction, and (3) Factor rotation and interpretation" (Ozdamar, 2017). A confirmatory factor analysis was then carried out and the result transferred to SmartPLS 3 software for further analysis.

\section{Results of the Study}

\subsection{Reliability and Validity of Scales}

The data was first analyzed to ensure instrument quality by convergent and discriminant validity. Applying SPSS, the exploratory factor analysis (EFA) was conducted to measure the underlying dimension associated with 49 items. The Bartlett's test of Sphericity and Kaiser-Mayer-Olkin (KMO) measure of the sampling adequacy were used to measure the construct. To perform factor analysis, the KMO score should be 0.6 or above (Ozdamar, 2017). The result of the Bartlett's Test of Sphericity and KMO shows that the scales adopted for the study are suitable for the factor analysis Table 1. It shows a Chi-square value of 27607.538 and significant value $(p>0.000)$.

Table-1. KMO and Bartlett's test.

\begin{tabular}{|c|c|c|}
\hline \multicolumn{2}{|c|}{ Kaiser-Meyer-Olkin Measure of Sampling Adequacy. } & .763 \\
\hline \multirow[t]{3}{*}{ Bartlett's Test of Sphericity } & Approx. Chi-Square & 27607.538 \\
\hline & Df & 1176 \\
\hline & Sig. & .000 \\
\hline
\end{tabular}

\subsection{Demographic Characteristics of Respondents}

Some demographic variables were collected in this study. These include gender, age, level of education, department, work experience, salary and marital status see Table 2.

Table-2. Demographics of respondents

\begin{tabular}{|c|c|c|}
\hline Variable & Category & No (\%) \\
\hline \multirow[t]{2}{*}{ Gender } & Male & $392(76.1)$ \\
\hline & Female & $123(23.9)$ \\
\hline \multirow[t]{3}{*}{ Age (years) } & $20-30$ & $219(42.5)$ \\
\hline & $31-40$ & $246(47.8)$ \\
\hline & $41-50$ & $50(9.7)$ \\
\hline \multirow{3}{*}{$\begin{array}{l}\text { Level of } \\
\text { education }\end{array}$} & Bachelor's Degree & $216(46.9)$ \\
\hline & Master's level & $291(56.5)$ \\
\hline & PhD degree & $8(1.6)$ \\
\hline \multirow{5}{*}{ Department } & $\mathrm{HR}$ & $35(6.8)$ \\
\hline & Financial & $8(1.6)$ \\
\hline & Sales \& Marketing & $218(42.3)$ \\
\hline & Administration & $45(8.7)$ \\
\hline & Others & $209(40.6)$ \\
\hline \multirow{4}{*}{$\begin{array}{c}\text { Work } \\
\text { experience }\end{array}$} & 1 to 5 years & $127(24.7)$ \\
\hline & 6 to 10 years & $260(50.5)$ \\
\hline & 11 to 15 years & $125(24.3)$ \\
\hline & 16 years and above & $3(0.6)$ \\
\hline \multirow[t]{4}{*}{ Salary } & below 20,000 & $11(2)$ \\
\hline & 20,000 To 40,000 & $177(34)$ \\
\hline & 40,000 То 60,000 & $159(31)$ \\
\hline & Above 60,000 & $168(33)$ \\
\hline \multirow[t]{2}{*}{ Marital status } & Married & $340(66)$ \\
\hline & Single & $175(34)$ \\
\hline
\end{tabular}

Table 2 shows the demographics of respondents; $76.1 \%$ of the respondents are males and $23.9 \%$ are females. In terms of gender, $42.5 \%$ of the respondents were between 20 and 30 years; $47.8 \%$ are between 31 and 40 years; and $9.7 \%$ are between the ages of 41 and 50 . With regards to the educational qualification of the respondents, $46.9 \%$ of the respondents have a bachelor's degree; $56.5 \%$ have master's level qualification; and $1.6 \%$ have Ph.D. qualifications. Table 2 further shows that $6.8 \%$ of the respondents work in the HR department; $1.6 \%$ work in the financial department; $42.3 \%$ in the marketing \& sales department; $8.7 \%$ work in the administration; and $40.6 \%$ work in other departments. Also, $24.7 \%$ of the respondents have worked in the company between 1 to 5 years; $50.5 \%$ 
between 6 to 10 years; $24.3 \%$ also worked between 11 to 15 years; and 0.6 have worked for over 16 years. With regards to the salary of respondents $2 \%$ receive below 20,$000 ; 34 \% 20,000$ to 40,$000 ; 31 \%$ receive 40,000 to 60,000 ; and $33 \%$ receive more than 60,000 . Also, regarding the marital status of respondents, $66 \%$ are married; and $34 \%$ are single see Table 2.

Table-3. Factor loading and Construct Reliability.

\begin{tabular}{|c|c|c|c|c|c|}
\hline & FL & CA & rho_A & CR & AVE \\
\hline BS_1 & 0.781 & \multirow{6}{*}{0.880} & \multirow{6}{*}{0.888} & \multirow{6}{*}{0.909} & \multirow{6}{*}{0.626} \\
\hline BS_2 & 0.802 & & & & \\
\hline BS_3 & 0.760 & & & & \\
\hline BS_4 & 0.838 & & & & \\
\hline BS_5 & 0.843 & & & & \\
\hline BS_6 & 0.715 & & & & \\
\hline EJS_1 & 0.836 & \multirow{4}{*}{0.855} & \multirow{4}{*}{0.857} & \multirow{4}{*}{0.902} & \multirow{4}{*}{0.696} \\
\hline EJS_2 & 0.822 & & & & \\
\hline EJS_3 & 0.861 & & & & \\
\hline EJS_4 & 0.818 & & & & \\
\hline HAW_1 & 0.927 & \multirow{3}{*}{0.901} & \multirow{3}{*}{0.905} & \multirow{3}{*}{0.938} & \multirow{3}{*}{0.835} \\
\hline HAW_2 & 0.923 & & & & \\
\hline HAW_3 & 0.891 & & & & \\
\hline JI_1 & 0.787 & \multirow{8}{*}{0.890} & \multirow{8}{*}{0.892} & \multirow{8}{*}{0.912} & \multirow{8}{*}{0.566} \\
\hline JI_2 & 0.759 & & & & \\
\hline JI_3 & 0.761 & & & & \\
\hline JI_4 & 0.739 & & & & \\
\hline JI_5 & 0.707 & & & & \\
\hline JI_6 & 0.745 & & & & \\
\hline JI_7 & 0.798 & & & & \\
\hline JI_8 & 0.715 & & & & \\
\hline JSTY_1 & 0.820 & \multirow[t]{4}{*}{0.838} & \multirow[t]{4}{*}{0.846} & \multirow[t]{4}{*}{0.891} & \multirow[t]{4}{*}{0.672} \\
\hline JSTY_2 & 0.852 & & & & \\
\hline JSTY_3 & 0.840 & & & & \\
\hline JSTY_4 & 0.765 & & & & \\
\hline LSP_1 & 0.748 & \multirow{8}{*}{0.915} & \multirow{8}{*}{0.922} & \multirow{8}{*}{0.930} & \multirow{8}{*}{0.626} \\
\hline LSP_2 & 0.828 & & & & \\
\hline LSP_3 & 0.782 & & & & \\
\hline LSP_4 & 0.777 & & & & \\
\hline LSP_5 & 0.807 & & & & \\
\hline LSP_6 & 0.786 & & & & \\
\hline LSP_7 & 0.852 & & & & \\
\hline LSP_8 & 0.745 & & & & \\
\hline WE_1 & 0.762 & \multirow{3}{*}{0.742} & \multirow{3}{*}{0.746} & \multirow{3}{*}{0.854} & \multirow{3}{*}{0.661} \\
\hline WE_2 & 0.810 & & & & \\
\hline WE_3 & 0.864 & & & & \\
\hline
\end{tabular}

According to Table 3, all the measured variables had Cronbach's alphas above 0.70, indicating high reliability for the constructs. The validity of the constructs was achieved through the construct validity assessment. It is assessed through convergent validity and discriminant validity (Ringle, Wende, \& Becker, 2015). Convergent validity was considered adequate since the average variance extracted (AVEs) and composite reliability (Wright \& Cropanzano, 2007) satisfied the minimum of 0.50 and 0.70 respectively (Fornell \& Larcker, 1981).

Table-4. Discriminant Validity

\begin{tabular}{l|l|l|l|l|l|l|l}
\hline & BS & EJS & HW & JI & JS & LSP & WE \\
\hline BS & 0.791 & & & & & & \\
\hline EJS & 0.554 & 0.835 & & & & & \\
\hline HW & 0.473 & 0.573 & 0.914 & & & & \\
\hline JI & 0.473 & 0.841 & 0.516 & 0.752 & & & \\
\hline JS & 0.684 & 0.536 & 0.474 & 0.523 & 0.820 & & \\
\hline LSP & 0.351 & 0.510 & 0.451 & 0.585 & 0.481 & 0.791 & \\
\hline WE & 0.411 & 0.816 & 0.514 & 0.791 & 0.424 & 0.514 & 0.813 \\
\hline
\end{tabular}

Table 4 also shows discriminant validity and requires that the variables load higher than any other constructs on its scale. From Table 2, discriminant validity was achieved since the factors loaded higher on their scales. Benefits had a value of (0.79), Employee job satisfaction (0.83), Happiness at work (0.9), Job Inspiration (0.75), Job security (0.8), Leadership (0.8) and Work environment (0.8).

\subsection{Results of Structural Model}

The assessment of the structural model was done using regression weights, t-values, and p-values for the significance of t-statistics (Chin, 2010). The results of structural model for testing the research hypotheses are presented in Table 5 . 


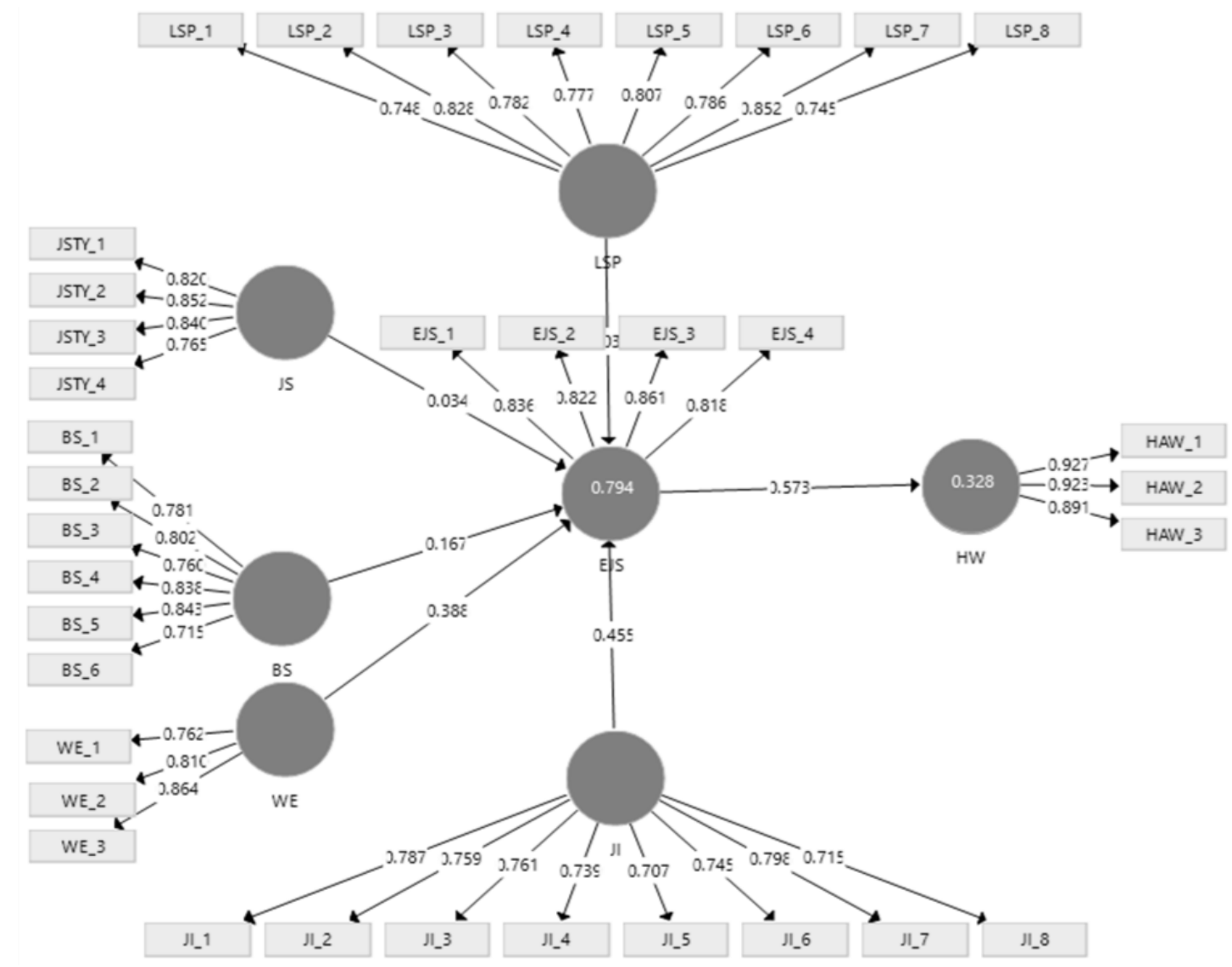

Figure-2. Structural model of relationship between job satisfaction and happiness at work.

Figure 2 the structural model's assessment regarding the relationship between the variables. The assessment includes the path coefficients that estimate the relationship between the variables. From Figure 2, employee job satisfaction related positively with job inspiration, benefits, job security, working environment, and leadership. Job inspiration had the highest influence on employee job satisfaction (45.4\%), followed by work environment (38.8\%); and benefits (16. 7\%). Leadership, on the other hand, had a negative relationship with $(-3.1 \%)$ respectively. It is expected that organizations would focus on these factors to get the result out of employees as these are the core issues influencing employee satisfaction. Also, employee job satisfaction had a positive relationship with happiness at work (57.3\%). What this means is that, once employees feel satisfied at the workplace, they would find happiness which is needed in ensuring employees work hard to achieve targeted goals and objectives thereby ensuring organisational performance.

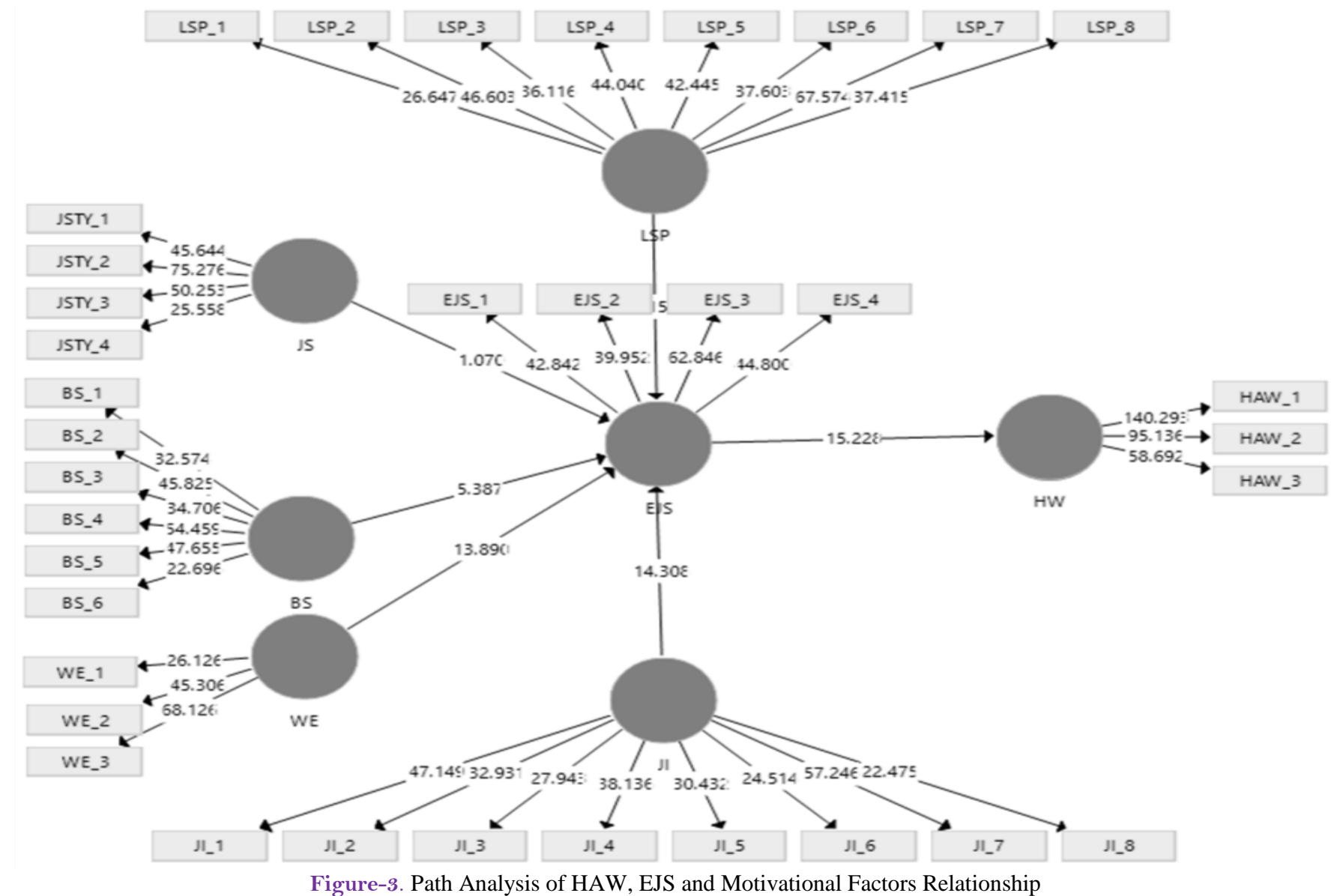

\subsection{Hypothesis Test}

A test for hypothesis was done using bootstrapping with 5000 samples on factors that influence or determine happiness at work. Benefits, Job inspiration, and Work environment had a positive and significant relationship with 
Employee Job satisfaction (EJS). Also, Job Satisfaction had a direct positive influence on Happiness at work. Benefits had a positive and significant effect on EJS $(\beta=0.167 ; t=5.39 ; \mathrm{p}<0.001)$; this led to the acceptance of hypothesis 1 . The Beta score 0.167 means that, when employee's benefits increase by $1 \%$, employee job satisfaction improves by $16.7 \%$. This means that employee benefit has a positive effect on the satisfaction of employees. Job inspiration had a significant and positive effect on EJS $(\beta=0.455 ; \mathrm{t}=14.3 ; \mathrm{p}<0.001)$; this led to the acceptance of hypothesis 2. This means that when employees are inspired by the kind of work they do, they would find satisfaction with the work they do see Table 5 .

Job security also had a positive but insignificant relationship with employee job satisfaction $(\beta=0.034 ; \mathrm{t}=$ 1.07; $\mathrm{p}>0.05)$; hypothesis H3 was therefore not accepted. Leadership also had a negative and insignificant effect on employee job satisfaction $(\beta=-0.031 ; \mathrm{t}=0.03 ; \mathrm{p}>0.05)$; $\mathrm{H} 4$ was also not accepted (see Table 5 ). Work environment had a positive and significant effect on $\operatorname{EJS}(\beta=0.388 ; \mathrm{t}=13.89 ; \mathrm{p}<0.001)$; this led to the acceptance of H5. Employees' job satisfaction also had a positive and significant effect on Happiness at work $(\beta=0.573$; $\mathrm{t}=$ 15.23; $\mathrm{p}<0.001)$; this led to the acceptance of H6. The Beta score means that when employee job satisfaction improves by $1 \%$, employees' happiness at work improves by about $57.3 \%$.

Table-5. Results of hypothesis test.

\begin{tabular}{c|c|c|c|c|c}
\hline Hypothesis & Path & $\boldsymbol{\beta}$ & STDEV & t-value & p-value \\
\hline HI & BS -> EJS & 0.167 & 0.031 & 5.39 & $* * *$ \\
\hline H2 & JI -> EJS & 0.455 & 0.032 & 14.31 & $* * *$ \\
\hline H3 & JS -> EJS & 0.034 & 0.032 & 1.07 & 0.29 \\
\hline H4 & LSP -> EJS & -0.031 & 0.031 & 0.03 & 0.25 \\
\hline H5 & WE -> EJS & 0.388 & 0.028 & 13.89 & $* * *$ \\
\hline H5 & EJS -> HW & 0.573 & 0.038 & 15.23 & $* * *$ \\
\hline
\end{tabular}
$73 \%$.

The R squared score shows that, together, the independent variables influenced happiness at work by about

Table-6. Indirect effect of BS, JI, JSTY, LSP and WE on Happiness at work.

\begin{tabular}{c|c|c|c|c}
\hline Paths & B & STDEV & t-value & p-value \\
\hline BS -> EJS -> HW & 0.103 & 0.0195 & 5.526 & 0.000 \\
\hline JI -> EJS -> HW & 0.270 & 0.028 & 9.702 & 0.000 \\
\hline JSTY -> EJS -> HW & 0.003 & 0.020 & 0.166 & 0.869 \\
\hline LSP -> EJS -> HW & -0.005 & 0.016 & 0.285 & 0.776 \\
\hline WE -> EJS -> HW & 0.207 & 0.019 & 11.165 & 0.000 \\
\hline
\end{tabular}

Table 6 shows the indirect effect in the relationship between the endogenous and exogenous variables. The table shows that benefits, job inspiration, and work environment influence Happiness at work indirectly through employee job satisfaction. BS had a positive and significant effect on $\mathrm{HW}(\beta=0.103 ; \mathrm{t}=5.526 ; \mathrm{p}<0.001)$. The Beta score here means that, when employees benefit improves by $1 \%$, employees' happiness at work also increases by about $10 \%$. Also, JI had a positive and significant effect on HW $(\beta=0.270 ; \mathrm{t}=9.70 ; \mathrm{p}<0.001)$; WE also had a positive and significant effect on $\mathrm{HW}(\beta=0.207 ; \mathrm{t}=11.165 ; \mathrm{p}<0.001)$.

\section{Discussion}

First, this study revealed that the factors that determine or influence employees' job satisfaction are job inspiration, benefits, job security, and leadership in that order. Job inspiration contributes more significantly to employee job satisfaction (45.5\%); followed by work environment (38.8\%), benefits (16.7\%) and job security (3.4\%). Leadership, however, contributed negatively to employee job satisfaction (-3.1\%). This finding is significant as it shows the factors that employers should concentrate or focus on to ensure employee job satisfaction thereby increasing employees' happiness at work.

Secondly, with regards to the hypotheses stated in this study, the findings show that four out of the six hypotheses stated were supported. Thus hypothesis $\mathrm{H}_{1}, \mathrm{H}_{2}, \mathrm{H} 5$, and $\mathrm{H}_{6}$ were all supported by this research's findings. The first hypothesis revealed a positive and significant relationship between Benefits/salaries and employee happiness. This finding indicates that the more inspiring work is for employees the satisfied they become doing their job. It further implies that when employees are satisfied with their assigned jobs and tasks, they and are able to achieve their work goals and output. As noted by Fisher (2010) job characteristics such as stable job, challenging and interesting work produce positive work attitudes, which then lead to satisfaction.

Hypothesis two also revealed a positive relationship between job inspiration and employee job satisfaction. This finding indicates that when employees perceive to be offered adequate compensation for their work, they would be satisfied with the work they do. It further implies that wages or salaries are very important to the work of employees. This finding supports empirical results that state that job inspiration have positive influence on employee job satisfaction (Khan. et al., 2012; Nguyen et al., 2003; Tessema \& Soeters, 2006).

Also, the study found a positive but insignificant relationship between job security and employee job satisfaction. When employees feel that they are insulated or secured from being fired from their job, nothing comes between their satisfaction and the work they do. As noted by Sageer et al. (2012) employees are always on the alert fearing the possibility that their employment could be terminated and this would affect their level of satisfaction and happiness at the workplace. It is important for management and organisational heads therefore to provide guarantee of job tenure for employees to insulate them from premature sack or from the organisation.

The fourth hypothesis also revealed a positive but insignificant relationship between leadership and happiness at work. This finding, however, contradicts earlier findings that found a significant relationship between leadership and employee job satisfaction (Orthodoxia et al., 2019; Vermeeren et al., 2014). Perhaps what this study revealed is 
that the respondents are not really satisfied with the leadership style operated in their organisation. Leadership is about motivating people to move in the desired direction that the organisation wants to move in order to achieve the goals and objectives stated. Employees would thus contribute towards the attainment of organizational goals and objectives when they are happy with the style of leadership and how they are directed. Effective leaders would thus consider employee's feelings and know how to inspire, stimulate and give meaning to employee's work (Cleavenger \& Munyon, 2013; Vasconcelos, 2008). Also, as noted by Dimitrov (2012); MacMillan (2009) when employees note the importance of their work to management, they can be more motivated and satisfied with their work.

The fifth hypothesis also revealed a positive relationship between the work environment and employees' job satisfaction. When employees work in an environment that fosters spirit of togetherness, there is every reason for employees to be happy and this happiness might have a positive effect on how they work in the organisation. Also, employees need good working conditions with all the necessary tools at their disposal in order to carry on with their assigned tasks. Failure to do so would mean that employees would have to compromise and work with the available tools and materials which would not lead to their satisfaction.

Furthermore, this study found a positive and significant relationship between employee job satisfaction and happiness at work. When employees are satisfied with the work they do, it influences their happiness at work. It is imperative that organisational leaders focus on ensuring employee happiness by making working conditions safe, providing needed support for employees in carrying out their work diligently and going the extra mile in showing concern about employee well-being. This finding supports what (Lee, Grace, Sirgy, Singhapakdi, \& Lucianetti, 2018) stated that employees' positive experiences in work-life i.e. job satisfaction and quality of work-life can have a positive effect on employee's satisfaction and happiness.

Again, the findings show that there is an indirect relationship between benefits, job inspiration, work environment, and Happiness at work. Benefits, work environment, and job inspiration positively influence employees' happiness at work through employee job satisfaction. This means that factors influencing employee satisfaction could also indirectly influence employees 'happiness at work. Organizations must, therefore, strive to ensure the satisfaction of employees at all times.

\section{Conclusions}

This study investigated the effect of employee job satisfaction on employees' happiness at work among telecommunication workers in Pakistan. Findings from the study show that benefits, job inspiration, and work environment influence employee happiness as well as employees' happiness at work. Thus, ensuring good working environment and providing adequate compensation that is commensurate to the work employees do would ensure employee satisfaction and by extension employee happiness. Once this is achieved, not only would employees be happy, but would go a long way to enhance the productivity of employees which would lead to organisational performance. It is up to management therefore to identify the needs and aspirations of their employees as well as know the source of employees' happiness.

\section{References}

Achor, S. (2010). The happiness advantage: The seven principles that fuel success and performance at work. New York: Virgin Books.

Arsic, M., Nikolic, D., Zivkovic, Z., Urosevic, S., \& Mihajlovic, I. (2012). The effect of TQM on employee loyalty in transition economy, Serbia. Total Quality Management \& Business Excellence, 23(5-6), 719-729. Available at: https://doi.org/10.1080/14783363.2012.669930.

Asiyabi, M., \& Mirabi, V. (2012). Investigation of contributing factors in employees desertion in power engineering consultants (Moshanir) company. Interdisciplinary Journal of Contemporary Research in Business, 4(6), 1183-1199.

Bakotic, D., \& Babic, T. B. (2013). Relationship between working conditions and job satisfaction: The case of croatian shipbuilding company. International Journal of Business and Social Science, 4(2), 206-213.

Brief, A. P. (1998). Attitudes in and around organizations. CA: Thousand Oaks: Sage Publications.

Buhai, S., Cottini, E., \& Nielseny, N. (2008). The impact of workplace conditions on firm performance. Working Paper No. 08-13.

Cahn, S., \& Vitrano, C. (2008). Happiness: Classic and contemporary readings in philosophy. Oxford: Oxford University Press.

Chin, W. (2010). How to write up and report PLS analyses. In C. W. W. Esposito, V. Vinzi, J. Henseler \& H. Wang (Eds.), Handbook of partial least squares: Concepts, methods and applications (pp. 655 - 690). Heidelberg: Springer.

Cleavenger, D. J., \& Munyon, T. P. (2013). It's how you frame it: Transformational leadership and the meaning of work. Business Horizons, 56(3), 351-360. Available at: https://doi.org/10.1016/j.bushor.2013.01.002.

De Witte, H., De Cuyper, N., Handaja, Y., Sverke, M., Näswall, K., \& Hellgren, J. (2010). Associations between quantitative and qualitative job insecurity and well-being: A test in Belgian banks. International Studies of Management \& Organization, 40(1), 40-56. Available at: https://doi.org/10.2753/imo0020-8825400103.

Dimitrov, D. (2012). Sources of meaningfulness in the workplace: A study in the US hospitality sector. European Journal of Training and Development, 36(2/3), 351-371. Available at: https://doi.org/10.1108/03090591211204788.

Fisher, C. D. (2010). Happiness at work. International Journal of Management Reviews, 12, 384-412. Available at: http://dx.doi.org/10.1111/j.1468-2370.2009.00270.x.

Fornell, C., \& Larcker, D. F. (1981). Evaluating structural equation models with unobservable variables and measurement error. Journal of Marketing Research, 18(1), 39-50. Available at: https://doi.org/10.1177/002224378101800104.

Gazioglu, S., \& Tansel, A. (2006). Job satisfaction in Britain: Individual and job related factors. Applied Economics, 38(10), $1163-1171$. Available at: https://doi.org/10.1080/00036840500392987.

Gu, J., Zhen, T., Song, Y., \& Xu, L. (2019). Job satisfaction of certified primary care physicians in rural Shandong Province, China: A crosssectional study. BMC Health Services Research, 19(1), 75. Available at: https://doi.org/10.1186/s12913-019-3893-8.

Hee, O. C., Yi, H. S., Ping, L. L., Kowang, T. O., \& Fei, G. C. (2019). Factors influencing job satisfaction in the palm oil industry in Malaysia. International Journal of Academic Research in Business and Social Sciences, 9(2), 516-527.

Herzberg, F. (1968). One more time: How do you motivate employees? Harvard Business Review, 46(1), 53-62.

Jun, M., Cai, S., \& Shin, H. (2006). TQM practice in maquiladora: Antecedents of employee satisfaction and loyalty. Journal of Operations Management, 24(6), 791-812. Available at: https://doi.org/10.1016/j.jom.2005.09.006.

Khan, A. H., Nawaz, M. M., Aleem, M., \& Hamed, W. (2015). Impact of job satisfaction on employee performance: An empirical study of autonomous Medical Institutions of Pakistan. African Journal of Business Management, 6(7), 2697-2705. Available at: $10.5897 /$ AJBM 11.2222 .

Khan., H. A., Nawaz, M. M., Aleem, M., \& Hamed, W. (2012). Impact of job satisfaction on employee performance: An empirical study of autonomous Medical Institutions of Pakistan. African Journal of Business Management, 6(7), 2697-2705.

Khuong, M. N., \& Tien, B. D. (2013). Factors influencing employee loyalty directly and indirectly through job satisfaction-A study of banking sector in Ho Chi Minh City. International Journal of Current Research and Academic Review, 1(4), 81-95. 
Lee, D. J., Grace, B. Y., Sirgy, M. J., Singhapakdi, A., \& Lucianetti, L. (2018). The effects of explicit and implicit ethics institutionalization on employee life satisfaction and happiness: The mediating effects of employee experiences in work life and moderating effects of work-family life conflict. Journal of Business Ethics, 147(4), 855-874. Available at: https://doi.org/10.1007/s 10551-015-2984-7.

MacMillan, S. (2009). Towards an existential approach to the meaning of work. Unpublished PhD's Thesis, Saint Mary's University, Canada.

McGonagle, C. (2015). Happiness in the workplace: An appreciative inquiry. Unpublished PhD's Thesis, Dublin City University, Dublin.

Meier, S., \& Stutzer, A. (2008). Is volunteering rewarding in itself? Economica, 75(297), 39-59.

Nguyen, A., Taylor, J., \& Bradley, S. (2003). Relative pay and job satisfaction: Some new evidence. MPRA Paper No 1382. University Library of Munich, Germany.

Orthodoxia, P., Kourtesopoulou, E. N., \& Kriemadis, A. (2019). The relationship between leadership behaviors and job satisfaction: The case of athens municipal sector. Business \& Entrepreneurship Journal, 8(1), 49-62.

Ozdamar, K. (2017). Scale and test development with application of structural equation modeling IBM SPSS, IBM SPSS AMOS and Minitab. [Scale and test development Structural equation modeling IBM SPSS, IBM SPSS AMOS and Minitab applied]. Eskişehir: Nisan Kitabevi.

Pearson, C. (1991). An assessment of extrinsic feedback on participation, role perceptions, motivation, and job satisfaction in a self-managed system for monitoring group achievement. Human Relations, 44(5), 517-537. Available at: https://doi.org/10.1177/001872679104400506.

Raziq, A., \& Maulabakhsh, R. (2015). Impact of working environment on job satisfaction. Paper presented at the 2nd Global Conference on Business, Economics, Management and Tourism, Prague, Czech Republic.

Rice, R. W., McFarlin, D. B., \& Bennett, D. E. (1989). Standards of comparison and job satisfaction. Journal of Applied Psychology, 74(4), 591598. Available at: https://doi.org/10.1037/0021-9010.74.4.591.

Ringle, C. M., Wende, S., \& Becker, J. M. (2015). SmartPLS 3. Hamburg: SmartPLS.

Ryff, C. D., \& Singer, B. H. (2008). Know thyself and become what you are: A eudaimonic approach to psychological well-being. Journal of Happiness Studies, 9(1), 13-39. Available at: https://doi.org/10.1007/s 10902-006-9019-0.

Sageer, A., Rafat, S., \& Agarwal, P. (2012). Identification of variables affecting employee satisfaction and their impact on the organization. IOSR Journal of Business and Management, 5(1), 32-39. Available at: https://doi.org/10.9790/487x-0513239.

Siegall, M., \& McDonald, T. (2004). Person-organization value congruence, burnout and diversion of resources. Personnel Review, 33(3), 291301. Available at: http://dx.doi.org/10.1108/00483480410528832.

Skalli, A., Theodossiou, I., \& Vasileiou, E. (2008). Jobs as Lancaster goods: Facets of job satisfaction and overall job satisfaction. The Journal of Socio-Economics, 37(5), 1906-1920. Available at: https://doi.org/10.1016/j.socec.2008.04.003.

Sohail, M. S., \& Jang, J. (2017). Understanding the relationships among internal marketing practices, job satisfaction, service quality and customer satisfaction: An empirical investigation of Saudi Arabia's service employees. International Journal of Tourism Sciences, $17(2), 67-85$. Available at: https://doi.org/10.1080/15980634.2017.1294343.

Sowmya, K., \& Panchanatham, N. (2011). Factors influencing job satisfaction of banking sector employees in Chennai, India. Journal of Law and Conflict Resolution, 3(5), 76-79.

Spector, P. (1997). Job satisfaction: Application, assessment, causes and consequences (Vol. 3). Thousand Oaks Inc.: CA: Sage Publications.

Stoi, E. (2016). Happiness and well-being at work. Unpublished Master's Thesis, Universitat Jaume

Tadić, M., Bakker, A. B., \& Oerlemans, W. G. (2013). Work happiness among teachers: A day reconstruction study on the role of selfconcordance. Journal of School Psychology, 51(6), 735-750. Available at: https://doi.org/10.1016/j.jsp.2013.07.002.

Tariq, M., Ramzan, M., \& Riaz, A. (2013). The impact of employee turnover on the efficiency of the organization. Interdiciplinary Journal of Contemporary Research in Business, 4(9), 700-711.

Tasnim, Z. (2016). Happiness at workplace: Building a conceptual framework. World, 6(2), 66-75.

Tessema, T. M., \& Soeters, J. L. (2006). Challenges and prospects of HRM in developing countries: Testing the HRM-performance link in the Eritrean civil service. The International Journal of Human Resource Management, 17(1), 86-105. Available at: https://doi.org/10.1080/09585190500366532.

Vasconcelos, A. F. (2008). Broadening even more the internal marketing concept. European Journal of Marketing, 42(11/12), 1246-1264. Available at: https://doi.org/10.1108/03090560810903664.

Vermeeren, B., Kuipers, B., \& Steijn, B. (2014). Does leadership style make a difference? Linking HRM, job satisfaction, and organizational performance. Review of Public Personnel Administration, 34(2), 174-195. Available at: https://doi.org/10.1177/0734371x 13510853.

Warr, P. (2007). Work, happiness, and unhappiness. Mahwah, NJ: Lawrence Erlbaum.

Wegge, J., Van Dick, R., Fisher, G. K., Wecking, C., \& Moltzen, K. (2006). Work motivation, organisational identification, and well-being in call centre work. Work \& Stress, 20(1), 60-83. Available at: https://doi.org/10.1080/02678370600655553.

Wesarat, P., Sharif, Y. M., \& Abdul Majid, A. (2015). A conceptual framework of happiness at the workplace. Asian Social Science, $11(2)$, $78-88$. Available at: https://doi.org/10.5539/ass.v $11 \mathrm{n} 2 \mathrm{p} 78$.

Wright, T. A., \& Cropanzano, R. (2007). The happy/productive worker thesis revised. In J. Martocchio (Ed.), Research in personnel and human resource management (Vol. 26, pp. 269-313). Amsterdam, The Netherlands: Elsevier Ltd.

Citation | Rehan Sohail Butt; Xuezhou Wen; Rana Yassir Hussain (2020). Mediated Effect of Employee Job Satisfaction on Employees' Happiness at Work and Analysis of Motivational Factors: Evidence Happiness at Work and Analysis of Motivational Factors: Evidence
from Telecommunication Sector. Asian Business Research Journal, 5: 19-27.

\section{History:}

Received: 30 June 2020

Revised: 4 August 2020

Accepted: 16 August 2020

Published: 7 September 2020

Licensed: This work is licensed under a Creative Commons

Attribution 3.0 License (cc)

Publisher: Eastern Centre of Science and Education
Acknowledgement: All authors contributed equally to the conception and design of the study.

Funding: This study received no specific financial support.

Competing Interests: The authors declare that they have no competing interests.

Transparency: The authors confirm that the manuscript is an honest, accurate, and transparent account of the study was reported; that no vital features of the study have been omitted; and that any discrepancies from the study as planned have been explained.

Ethical: This study follows all ethical practices during writing.

Eastern Centre of Science and Education is not responsible or answerable for any loss, damage or liability, etc. caused in relation to/arising out of the use of the content. Any queries should be directed to the corresponding author of the article. 